\title{
Identifikasi Komponen Senyawa Dari Ekstrak Buah Laban (Vitex Pubescens Vahl) Fraksi Eter Dan Fraksi Kloroform
}

\author{
Ikhsaniati Afifah \\ SMA Negeri 1 Murung, Kalimantan Tengah, Indonesia \\ ikhsaniatiafifah@gmail.com
}

\begin{abstract}
Abstrak. Telah dilakukan penelitian tentang identifikasi komponen senyawa dari ekstrak buah laban fraksi eter dan fraksi kloroform. Penelitian ini bertujuan untuk mengetahui (1) Komponen senyawa yang terdapat dalam fraksi eter buah laban, dan (2) Komonen senyawa yang terdapat dalam fraksi kloroform ekstrak buah laban. Penelitian ini menggunakan metode eksperimen dengan pengamblan sampel menggunakan teknik sampling area purposive. Isolasi sampel menggunakan metode maserasi dengan pelarut metanol dan dilakukan fraksinasi dengan pelarut eter dan kloroform pada ekstrak metanol yang diperoleh. Analisis komponen senyawa dilakukan dengan KG-SM. Data dianalisis secara deskriptif kualitatif. Hasil penelitian, pada pemeriksaan pendahuluan menunjukkan adanya senyawa alkaloid, flavonoid, senyawa fenolik, dan kuinon. Berdasarkan KG-SM pada fraksi eter teridentifikasi 8 puncak senyawa dan empat senyawa yang berhasil diidentifikasi yaitu; 4-hidroksi-3-metoksi benzaldehida atau vanilin, 4hidroksi-3-metil benzoat atau metil paraben, 4-hidroksi-3-metoksi benzoat atau asam vanilat, 4-hidroksi benzoat atau paraben. Berdasarkan KG-SM pada fraksi kloroform teridentifikasi 60 puncak senyawa dengan lima senyawa yang berhasil diidentifikasi yaitu; $\alpha$-butil ester furoat, 4-hidroksi-3-metoksi-sinamaldehida, bis2-etil heksil adipat atau sicol, heksadekana, heptadekana.
\end{abstract}

Kata kunci : Laban (Vitex pubescens Vahl), maserasi, KG-SM

\section{PENDAHULUAN}

Bangsa Indonesia dianugerahi ALLAH SWT sumber daya alam yang luar biasa. Negara yang subur dengan sumber daya alam yang melimpah menjadikan Indonesia sebagai paru-paru dunia. Indonesia kaya akan berbagai jenis tumbuhan yang dapat memberikan manfaat pada berbagai bidang antara lain bidang pertanian, perkebunan, kehutanan, industri, farmasi, dan sebagainya. Hutan Kalimantan sendiri mempunyai kekayaan alam yang luar biasa, terbukti dari penelitian Kementrian Lingkungan Hidup (KLH) menemukan 200 jenis kayu hidup dalam setiap hektar hutan Kalimantan (Antara News, 2007).

Tumbuhan Laban (Vitex pubescens Vahl) merupakan salah satu kekayaan alam hutan Indonesia yang banyak tersebar di Sumatera, Jawa, Kalimantan, Lombok, Bali, dan Sulawesi (K. Heyne, 1987). Menurut Oeng Djoen Seng (Abidin, 1990) kayu laban oleh masyarakat terutama di Kalimantan Selatan 
digunakan sebagai bahan bakar dan bahan baku pembuatan arang. Kulit batang dan buah laban dimanfaatkan sebagai pewarna tradisional. Selain itu, kikisan kulit batang juga digunakan pada luka-luka dan air rebusannya diminum untuk obat sakit pinggang. Bahkan daunnya digunakan oleh orang Batak sebagai minuman seduhan pengganti kopi (K. Heyne, 1987). Buah laban sendiri dipercaya oleh masyarakat mempunyai manfaat dalam bidang kesehatan seperti untuk mengobati penyakit maag dan diduga mempunyai khasiat sebagai pemicu peningkatan energi dalam tubuh, namun sejauh ini, belum ada penelitian mengenai senyawa yang terkandung dalam tumbuhan ini khususnya pada buah laban dan belum dimanfaatkannya buah laban oleh masyarakat secara optimal.

Tumbuh-tumbuhan secara kimia dikenal banyak mengandung senyawasenyawa organik seperti flavonoid, alkaloid, terpenoid, steroid, dan senyawasenyawa organik lainnya. Senyawa-senyawa ini merupakan hasil metabolisme sekunder dari tumbuhan yang sampai saat ini masih menjadi perhatian para peneliti. Adanya senyawa-senyawa ini mempunyai berbagai fungsi bagi tumbuhan antara lain sebagai pengatur kerja hormon, penangkal serangan musuh, penambah daya tahan tubuh, dan sebagai daya tarik serangga untuk membantu penyerbukan. Bagi manusia senyawa-senyawa organik yang terkandung pada tumbuhan tersebut juga dapat bermanfaat karena banyak digunakan dalam berbagai keperluan seperti kesehatan, pemberantasan hama, dan sebagainya.

Mengingat potensi serta belum adanya penelitian terhadap kandungan senyawa kimia buah laban, maka perlu dilakukan penelitian lebih mendalam mengenai komonen senyawa buah laban terutama komponen senyawa yang terdapat pada fraksi eter dan fraksi kloroform.

\section{METODE PENELITIAN}

Metode penelitian yang dipakai adalah metode eksperimen. Pengisolasian komponen senyawa pada buah laban menggunakan metode maserasi dengan pelarut metanol, penentuan komponen senyawa serta strukturnya menggunakan instrumen KG-SM. 


\section{Alat dan Bahan Penelitian}

\section{a. Alat yang digunakan}

Alat yang digunakan dalam penelitian ini yaitu: neraca analitik, AND tipe GR 200, blender, gelas kimia 100 mL, 500 mL, dan 1000 mL, labu erlenmeyer $100 \mathrm{~mL}$ dan $500 \mathrm{~mL}$, labu pengenceran $25 \mathrm{~mL}$, corong pisah, corong kaca, batang pengaduk kaca, rotary evaporator RE300, waterbath RE300B, pipet tetes, pipet volum, $\mathrm{pH}$ meter, pengaduk magnet, botol sampel, statif dan klem, seperangkat alat KG-SM SHIMADZU QP 20108, dan aluminium foil.

\section{b. Bahan-bahan yang digunakan}

Bahan yang digunakan dala penelitian ini yaitu: aquades, asam sulfat, $\mathrm{HCl}$ pekat, bubuk $\mathrm{Mg}, \mathrm{NaOH} 10 \%, \mathrm{NAOH} 1 \mathrm{~N}, \mathrm{FeCl}_{3} 1 \%$, metanol (merck, p.a), kloroform, dietil eter, $\mathrm{HCl} 1 \mathrm{M}$, amoniak, pereaksi Meyer, kertas saring, dan vaselin

\section{Teknik Pengambilan Sampel}

Dalam penelitian ini pengambilan sampel menggunakan teknik sampling area purposive, di mana sampel yang diambil adalah buah laban yang ada di desa Muara Laung Kecamatan Laung Tuhup Kabupaten Murung Raya Kalimantan Tengah.

\section{Prosedur Penelitian}

\section{a. Identifikasi alkaloid}

Memotong-motong $4 \mathrm{~g}$ buah segar dan menggerus bersama dengan $10 \mathrm{~mL}$ kloroform. Menambahkan $10 \mathrm{~mL}$ kloroform-amoniak ke dalam hasil gerusan, mengaduk dan kemudian menyaring ke dalam tabung reaksi. Menambahkan 10 tetes larutan asam sulfat 5\% ke dalam ekstrak kloroform-amoniak, mengocok dan membiarkan kedua lapisan memisah. Memisahkan lapisan atas. Meneteskan 2 tetes pereaksi Meyer pada lapisan atas. Alkaloid ditunjukkan dengan endapan putih atau kuning mda. 


\section{b. Identifikasi flavonoid}

(1) Dengan pereaksi Shinoda

Mengekstrak sebanyak 0,5 g serbuk sampel dengan $5 \mathrm{~mL}$ etanol panas selama 5 menit di dalam tabung reaksi. Selanjutnya menyaring hasil ekstrak dan kepada filtratnya menambahkan 2 tetes $\mathrm{HCl}$ pekat lalu menambahkan 0,2 g bubuk Mg. Bila timbul warna merah muda atau orange menandakan sampel mengandung flavonoid.

(2) Dengan $\mathrm{NaOH} 10 \%$

Mengekstrak sebanyak 0,5 g serbuk sampel dengan $5 \mathrm{~mL}$ metanol panas selama 5 menit di dalam tabung reaksi. Selanjutnya menyaring hasil ekstrak dan ke dalam filtratnya menambahkan 2 tetes $\mathrm{NaOH} 10 \%$. Adanya flavonoid ditunjukkan dengan perubahan warna kuning - merah.

\section{c. Identifikasi kuinon}

Sampel diekstrak dengan air kemudian dididihkan. Larutan ekstrak ditambahkan dengan 5 tetes $\mathrm{NaOH} 1 \mathrm{~N}$. Adanya kuinon ditandai dengan terbentuknya warna merah.

\section{d. Identifikasi senyawa fenol sederhana}

Sampel diekstraksi dengan aquades kemudian dididihkan. Larutan ekstrak kemudian ditambahkan dengan $\mathrm{FeCl}_{3}$ 1\%. Adanya senyawa fenol ditandai dengan terbentuknya warna hijau, merah, ungu, biru, atau hitam yang kuat.

\section{e. Preparasi sampel}

Sebelum melakukan kegiatan penelitian sampel buah laban terlebih dahulu dibersihkan dari kotoran, selanjutnya dikeringkan di bawah sinar matahari langsung sampai beratnya relatif tudak berubah, kemudian dihaluskan dengan blender hingga menjadi serbuk.

\section{f. Isolasi senyawa pada buah laban}

Ekstraksi senyawa dari buah Laban (Vitex pubescens Vahl) dilakukan dengan menggunakan teknik maserasi. Sebanyak $250 \mathrm{~g}$ serbuk buah laban 
dimaserasi dengan metanol sebanyak $750 \mathrm{~mL}$ selama 1 × 24 jam kemudian dilakukan penyaringan. Residu yang diperoleh dimaserasi kembali dengan cara yang sama sebanyak dua kali pengulangan. Ekstrak metanol yang diperoleh dijadikan satu. Ekstrak metanol hasil maserasi kemudian dipekatkan dengan menggunakan rotary evaporator untuk menghasilkan ekstrak metanol yang pekat.

Ekstrak metanol diasamkan dengan asam klorida $(\mathrm{HCl}) 1 \mathrm{M}$ sampai $\mathrm{pH} 4$ dan didekantasi selama 1 malam. Larutan dipisahkan dari endapan yang terbantuk. Larutan dicuci dengan $100 \mathrm{~mL}$ dietil eter sebanyak 2 kali, fraksi eter yang diperoleh dipekatkan. Ke dalam larutan asam (filtrat) ditambahkan amoniak $\left(\mathrm{NH}_{4} \mathrm{OH}\right)$ setetes demi seetes sampai $\mathrm{pH}$ 9. Selanjutnya diekstraksi dengan $50 \mathrm{~mL}$ kloroform sebanyak 3 kali, ekstrak kloroform yang diperoleh dipekatkan. Ekstrak sisa diektraksi dengan metanol dan dipekatkan. Selanjutnya identifikasi komponen senyawa pada masing-masing fraksi (fraksi eter, fraksi kloroform, dan fraksi sisa metanol) dilakukan dengan KG-SM.

\section{g. Identifikasi dengan metode kromatografi gas-spektroskopi massa (KG-SM)}

Sampel ekstrak buah laban yang akan dipisahkan dibawaoleh gas pembawa (helium) dengan tekanan $16,5 \mathrm{kPa}$ melalui kolom Rtx-5MS dengan panjang 30 meter diameter $0,25 \mathrm{~mm}$ dan suhu kolom $80^{\circ} \mathrm{C}$, digunakan isi kolom yang bersifat medium/semipolar karena senyawa yang akan dianalisis masih belum dketahui sifat kepolarannya. Biasanya digunakan prinsip "rule of tongue" yaitu fase diam yang sedikit lebih polar daripada cuplikannya. Pita senyawa yang terbentuk meninggalkan kolom bersama aliran gas pembawa dan dicatat sebagai fungsi waktu oleh detektor pada suhu $320^{\circ} \mathrm{C}$. Selanjutnya dibawa spektra massa dengan menembak molekul senyawa dengan berkas elektron dan diubah menjadi ion molekul sehingga dapat dipecah menjadi ionion yang lebih kecil. 


\section{Teknik Analisis Data}

Kromatogram hasil kromatografi gas dianalisis secara deskriptif berdasarkan waktu retensi dan persen area senyawanya. Senyawa dengan persen area yang besar dianalisis lebih lanjut. Spektra hasil spektroskopi dianalisis berdasarkan data puncak ion molekul, puncak dasar (base peak) dan pola puncak ion fragmen mengacu pada data hit list.

\section{HASIL PENELITIAN DAN PEMBAHASAN}

\section{Hasil Uji Pendahuluan}

\section{a. Hasil uji pendahuluan alkaloid}

Hasil uji pendahuluan terhadap kandungan alkaloid pada buah laban dapat dilihat pada tabel berikut ini..

Tabel 1. Uji Pendahuluan Alkaloid

\begin{tabular}{|l|l|l|}
\hline No. & \multicolumn{1}{|c|}{ Percobaan } & \multicolumn{1}{|c|}{ Pengamatan } \\
\hline 1. & $\begin{array}{l}\text { Menggerus 0,5 g buah laban segar dengan } \\
\text { kloroform } \\
\text { Menambahkan 10 mL kloroform-amonia, } \\
\text { mengaduk dan menyaring } \\
\text { Menambahkan 10 tetes larutan asam sulfat } \\
5 \%\end{array}$ & $\begin{array}{l}\text { Ektrak berwarna ungu } \\
\text { Larutan berwarna keunguan } \\
\text { Terbentuk 2 lapisan } \\
\text { Lapisan atas bening agak } \\
\text { keruh } \\
\text { Lapisan bawah berwarna } \\
\text { keunguan }\end{array}$ \\
5. & $\begin{array}{l}\text { Mengambil lapisan atas (lapisan air) dan } \\
\text { menempatkan pada tabung reaksi } \\
\text { Meneteskan 2 tetes pereaksi Meyer ke kening agak keruh } \\
\text { dalam lapisan air }\end{array}$ & $\begin{array}{l}\text { Terbentuk endapan berwarna } \\
\text { kuning (+) }\end{array}$ \\
\hline
\end{tabular}

Berdasarkan hasil uji pendahuluan pada tabel di atas menunjukkan uji positif, yang berarti bahwa di dalam buah laban mengandung senyawa golongan alkaloid.

\section{b. Hasil uji pendahuluan flavonoid}

Hasil uji pendahuluan terhadap kandungan flavonoid pada buah laban dapat dilihat pada tabel 2 . 
Tabel 2. Hasil Pengamatan Flavonoid

\begin{tabular}{|l|l|l|}
\hline No. & \multicolumn{1}{|c|}{ Percobaan } & \multicolumn{1}{|c|}{ Pengamatan } \\
\hline 1. & $\begin{array}{l}\text { Pereaksi Shinoda } \\
\text { a. Mengekstrak 0,5 g buh laban segar } \\
\text { dengan 5 mL etanol panas } \\
\text { b. Menambahkan 2 tetes } \mathrm{HCl} \text { pekat dan } \\
0,2 \mathrm{~g} \text { bubuk } \mathrm{Mg} \\
\text { 2. }\end{array}$ & $\begin{array}{l}\text { Dengan NaOH 10\% } \\
\text { Mengekstrak 0,5 g buah laban segar } \\
\text { dengan metanol panas selam 5 menit, } \\
\text { menyaring } \\
\text { Menambahkan 2 tetes NaOH 10\% }\end{array}$ \\
$\begin{array}{l}\text { Larutan berwarna orange } \\
(+++)\end{array}$ \\
$\begin{array}{l}\text { Ekstrak berwarna ungu } \\
\text { Larutan berwarna kuning } \\
\text { kemerahan }(+++)\end{array}$ \\
\hline
\end{tabular}

Berdasarkan hasil uji pendahuluan pada Tabel di atas menunjukkan uji positif, yang berarti bahwa di dalam buah laban mengandung senyawa golongan flavonoid.

\section{c. Hasil uji pendahuluan senyawa fenolik}

Hasil uji pendahuluan terhadap kandungan senyawa fenolik pada buah laban dapat dilihat pada Tabel 3.

Tabel 3. Hasil Pengamatan Fenolik

\begin{tabular}{|l|l|ll|}
\hline No. & \multicolumn{1}{|c|}{ Percobaan } & \multicolumn{1}{|c|}{ Pengamatan } \\
\hline 1. & $\begin{array}{l}\text { Mengekstrak 0,5 g buah laban segar } \\
\text { dengan air, mendidihkan dan menyaring } \\
\text { 2. }\end{array}$ & $\begin{array}{l}\text { Ekstrak berwarna ungu } \\
\text { Menambahkan dengan } \mathrm{FeCl}_{3} 1 \%\end{array}$ & $\begin{array}{l}\text { Larutan berwarna biru } \\
\text { kehijauan (++++) }\end{array}$ \\
\hline
\end{tabular}

Berdasarkan hasil uji pendahuluan pada tabel di atas menunjukkan uji positif terhadap tanin, yang berarti bahwa di dalam buah laban mengandung senyawa fenolik.

\section{d. Hasil uji pendahuluan kuinon}

Hasil uji pendahuluan terhadap kandungan kuinon pada buah laban dapat dilihat pada tabel 4 .

Tabel 4. Hasil Pengamatan Kuinon

\begin{tabular}{|l|l|l|}
\hline No. & \multicolumn{1}{|c|}{ Percobaan } & \multicolumn{1}{|c|}{ Pengamatan } \\
\hline 1. & $\begin{array}{l}\text { Mengekstrak 0,5 g buah laban segar } \\
\text { dengan air, mendidihkan lalu menyaring } \\
\text { Menambahkan dengan NaOH }\end{array}$ & $\begin{array}{l}\text { Ekstrak berwarna ungu } \\
\text { Larutan berwarna merah } \\
(+++)\end{array}$ \\
\hline
\end{tabular}


Berdasarkan hasil uji pendahuluan pada tabel di atas menunjukkan uji positif, yang berarti bahwa di dalam buah laban mengandung senyawa kuinon.

\section{Hasil Isolasi Buah Laban}

Buah laban dibersihkan dan dikeringkan di bawah sinar matahari, kemudian dihaluskan sampai berbentuk serbuk. Serbuk buah laban kemudian ditimbang sebanyak 200 g. Ekstraksi yang dilakukan adalah dengan cara maserasi. Dilakukan cara maserasi karena cara ini merupakan cara yang paling sederhana dan tidak memerlukan alat khusus. Cara maserasi ini dilakukan 3 kali 24 jam, hal ini dilakukan supaya senyawa yang terkandung dalam buah laban dapat tertarik. Pelarut yang digunakan dalam proses maserasi ini adalah metanol (merck, p.a). Metanol digunakan sebagai pelarut karena metanol merupakan pelarut yang dapat melarutkan senyawa-senyawa yang terkandung dalam buah laban. Hasil isolasi senyawa buah laban dapat dilihat pada tabel 5.

\begin{tabular}{|c|c|c|}
\hline No. & Percobaan & Pengamatan \\
\hline 1. & Mengekstrak $200 \mathrm{~g}$ serbuk buah laban & Larutan ekstrak berwarna \\
\hline & $00 \mathrm{~mL}$ pelarut metanol $3 \times 24$ & kuning kecoklatan \\
\hline 2. & jam, menyaring & $\begin{array}{l}\text { Larutan agak pekat berwarna } \\
\text { coklat }\end{array}$ \\
\hline 3. & Menguapkan dengan rotary evaporator & Tidak terjadi perubahan pada \\
\hline & Menambahkan $\mathrm{HCl} 1 \mathrm{M}$ sampai $\mathrm{pH} 4$ & ekstrak \\
\hline 4. & $\begin{array}{l}\text { Melakukan ekstraksi cair-cair dengan } \\
\text { pelarut dietil eter, memisahkan fraksi eter }\end{array}$ & $\begin{array}{l}\text { Terbentuk } 2 \text { lapisan, lapisan } \\
\text { atas (fraksi eter berwarna } \\
\text { kekuningan dan lapisan } \\
\text { bawah ekstrak berwarna } \\
\text { cokelat }\end{array}$ \\
\hline 5. & $\begin{array}{l}\text { Malakukan ekstraksi dengan kloroform, } \\
\text { memisahkan fraksi kloroform }\end{array}$ & $\begin{array}{l}\text { Terbentuk } 2 \text { lapisan, lapisan } \\
\text { atas berwarna coklat dan } \\
\text { lapisan bawah (fraksi } \\
\text { kloroform) berwarna bening } \\
\text { kekuningan. }\end{array}$ \\
\hline 6. & $\begin{array}{l}\text { Menambahkan amoniak setetes demi } \\
\text { setetes sampai pH } 9 .\end{array}$ & $\begin{array}{l}\text { Larutan menjadi coklat } \\
\text { keruh }\end{array}$ \\
\hline 7. & $\begin{array}{l}\text { Mengekstraksi dengan kloroform, } \\
\text { memisahkan fraksi kloroform }\end{array}$ & $\begin{array}{l}\text { Terbentuk } 2 \text { lapisan, lapisan } \\
\text { atas kecoklatan dan lapisan } \\
\text { bawah (fraksi kloroform) } \\
\text { berwarna kekuningan }\end{array}$ \\
\hline 8. & $\begin{array}{l}\text { Mengekstraksi ekstrak sisa dengan metanol } \\
\text { dan memekatkan }\end{array}$ & Larutan berwrna coklat \\
\hline 9. & Memekatkan semua fraksi yang diperoleh & Ekstrak pekat \\
\hline
\end{tabular}




\section{Analisis Hasil Kromatografi Gas-Spektroskopi Massa (KG-SM) Ekstrak}

\section{Buah Laban.}

Hasil analisis senyawa ekstrak fraksi eter buah laban menggunakan alat KGSM diperoleh 8 puncak yang terlihat pada kromatogram gambar 1.

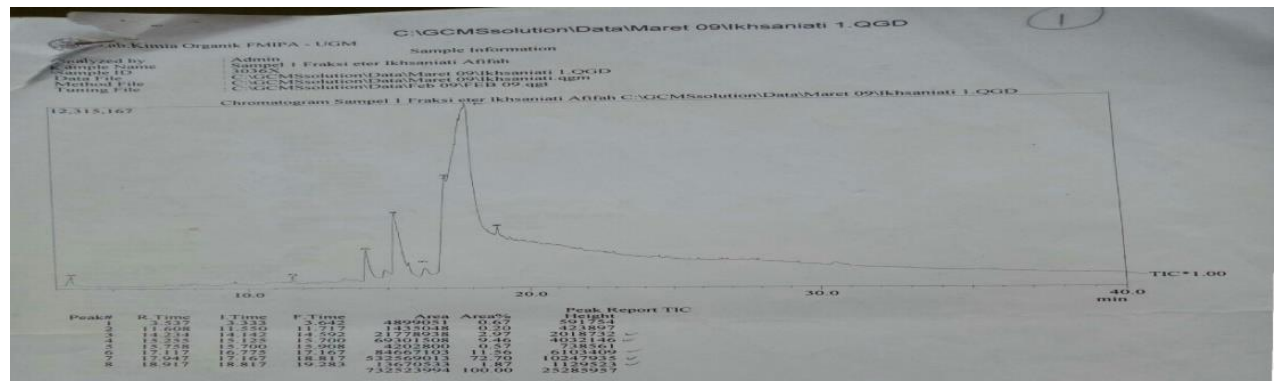

\section{Gambar 1. Kromatogram KG-SM} Fraksi Eter

Berdasarkan kromatogram yang diperoleh, terlihat ada 8 puncak yang muncul, yang berarti menunjukkan bahwa di dalam ekstrak buah laban fraksi eter terdapat 8 jenis senyawa. Dari kromatogram ini terdapat satu puncak senyawa dominan dari 8 puncak yang ada, yaitu pada puncak Nomor 7 dengan waktu retensi $\left(T_{R}\right)$ 17,947 dengan persentase $72,70 \%$. Selain itu terdapat juga 3 puncak lain yang mempunyai persentase cukup besar yaitu puncak Nomor 3, 4, dan 6 .

Jadi dari hasil kromatogram ekstrak buah laban fraksi eter di atas diperoleh 4 puncak senyawa yang persentasenya cukup besar. Besar persentase area masingmasing puncak dapat ditunjukkan pada Tabel 8.

Tabel 6. Waktu retensi dan persen area komponen fraksi eter ekstrak buah laban

\begin{tabular}{|c|c|c|c|c|c|c|}
\hline Peak & R. Time & I. Time & F. Time & Area & $\begin{array}{c}\text { Area } \\
\text { \% }\end{array}$ & $\begin{array}{c}\text { Peak report } \\
\text { ITC Height }\end{array}$ \\
\hline 3 & 15.255 & 14.142 & 14.592 & 21778938 & 2.97 & 2018732 \\
\hline 4 & 15.758 & 15.125 & 15.700 & 69301508 & 9.46 & 40321409 \\
\hline 6 & 17.117 & 16.775 & 17.167 & 84667103 & 1.56 & 6103409 \\
\hline 7 & 17.947 & 17.167 & 18.817 & 532569013 & 72.70 & 10247935 \\
\hline
\end{tabular}

Hasil analisis senyawa ekstrak fraksi kloroform buah laban menggunakan KG-SM diperoleh 60 puncak yang terlihat pada kromatogram Gambar 2. 


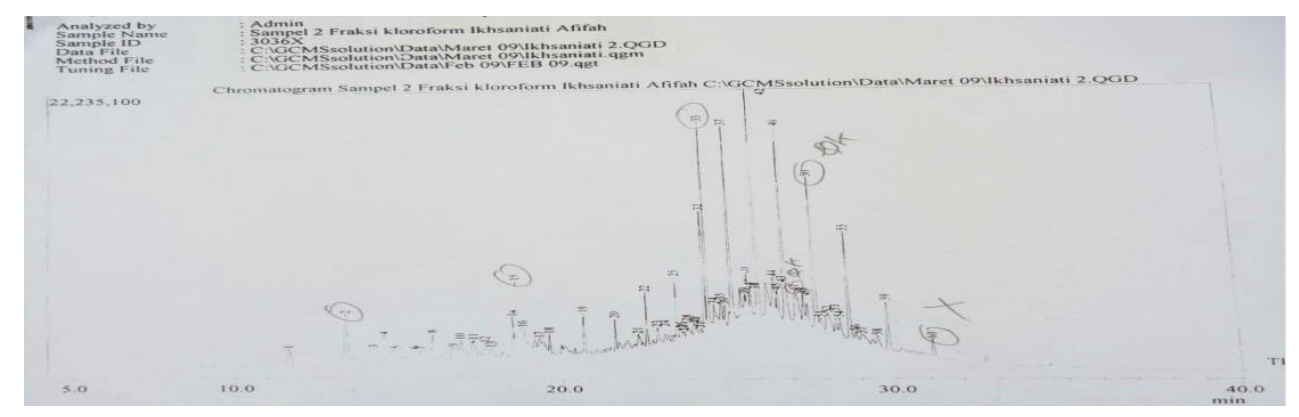

Gambar 2. Kromatogram KG-AM fraksi kloroform ekstrak buah laban

Berdasarkan kromatogram yang diperoleh, terlihat ada 60 puncak yang muncul, yang berarti menunjukan bahwa di dalam ekstrak buah laban fraksi kloroform terdapat 60 jenis senyawa. Namun, dari 60 puncak senyawa yang muncul hanya beberapa puncak yang bisa diidentifikasi berdasarkan data base yang ada. Dari kromatogram ini terdapat satu puncak senyawa dominan dari 60 puncak yang ada, yaitu pada puncak Nomor 42 dengan waktu retensi $\left(T_{R}\right)$ 26,072 dengan persentase $7,78 \%$. Namun, puncak tersebut tidak bisa diidentifikasi karena tidak terdapat hit list data base senyawanya. Selain itu terdapat juga 6 puncak yang mempunyai persentase cukup besar yaitu puncak Nomor 2, 15, 33, 47, 50, dan 60. Puncak Nomor 50 dan 60 mempunyai spektra massa yang sama persis, dan diperkirakan jenis senyawanya juga sama, sehingga pada puncak Nomor 60 tidak diidentifikasi lebih lanjut. Jadi dari hasil kromatogram ekstrak buah laban fraksi kloroform di atas diperoleh 5 puncak senyawa yang persentasenya cukup besar dan bisa diidentifikasi jenis senyawanya. Besar persentase area masingmasing puncak dapat ditunjukkan pada Tabel 9.

Tabel 7. Waktu retensi dan persen area komponen senyawa fraksi kloroform ekstrak buah laban

\begin{tabular}{|c|c|c|c|c|c|c|}
\hline Peak & R. Time & I. Time & F. Time & Area & Area \% & $\begin{array}{c}\text { Peak } \\
\text { refort } \\
\text { ITC } \\
\text { Height }\end{array}$ \\
\hline 2 & 13.430 & 13.317 & 13.597 & 223128773 & 1.85 & 3600926 \\
\hline 15 & 18.634 & 18.567 & 18.767 & 36117904 & 2.89 & 5357870 \\
\hline 33 & 24.525 & 24.458 & 24.633 & 62062744 & 4.96 & 17078515 \\
\hline 47 & 27.191 & 27.033 & 27.333 & 49809129 & 3.98 & 3965110 \\
\hline 50 & 27.779 & 27.642 & 27.842 & 58048744 & 4.64 & 12739091 \\
\hline
\end{tabular}




\section{Analisis Kromatografi gas-spektroskopi massa (KG-SM) pada fraksi eter ekstrak buah laban}

\section{a. Identifikasi Senyawa pada puncak $3 T_{R} 14,234$ dan $\%$ area 2,97}

Spektra massa senyawa ditunjukkan pada Gambar 3.

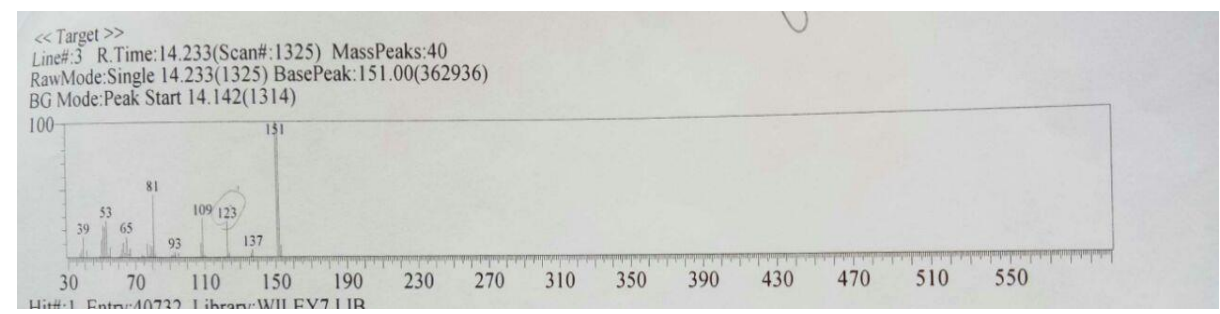

Gambar 3. Spektra massa senyawa puncak 3 fraksi eter pada $T_{R} 14,234$ dan $\%$ area 2,97

Pada spektra massa ditunjukkan pada gambar, tampak puncak ion molekul $\mathrm{M}^{+}-\mathrm{H} . \mathrm{m} / \mathrm{e}=151$. Berdasarkan data base KG-SM ditampilkan senyawa yang memiliki kemiripan 95\% dengan senyawa pada puncak 3. Senyawa tersebut adalah 4-hidroksi-3-metoksi benzaldehida (vanillin) dengan rumus molekul $\mathrm{C}_{8} \mathrm{H}_{8} \mathrm{O}_{3}$ dan harga $\mathrm{DBE}=5$. Puncak-puncak lainnya muncul pada $\mathrm{m} / \mathrm{e} 123$, 109, 81, 65, 53, dan 39. Pada m/e 151 merupakan puncak dasar. Senyawa pada $\mathrm{M}^{+}-\mathrm{H}$ m/e 151 melepaskan molekul CO menghasilkan fragmen m/e 123. Fragmen m/e 123 melepaskan molekul $\mathrm{CH}_{2}$ menghasilkan fragmen m/e 109 . Fragmen m/e 109 melepaskan atom $O$ menghasilkan fragmen m/e 93. Fragmen m/e 93 melepaskan atom $\mathrm{C}$ menghasilkan fragmen m/e 81. Fragmen m/e 81 melepaskan atom $\mathrm{O}$ menghasilkan fragmen m/e 65. Fragmen m/e 65 melepaskan atom $\mathrm{C}$ menghasilkan fragmen m/e 53. Fragmen m/e 53 melepaskan molekul $\mathrm{CH}_{2}$ menghasilkan fragmen m/e 39.

Pada fragmentasi dari senyawa 4-hidroksi-3-metoksi benzaldehida (vanillin) dijelaskan pada Gambar 4. 


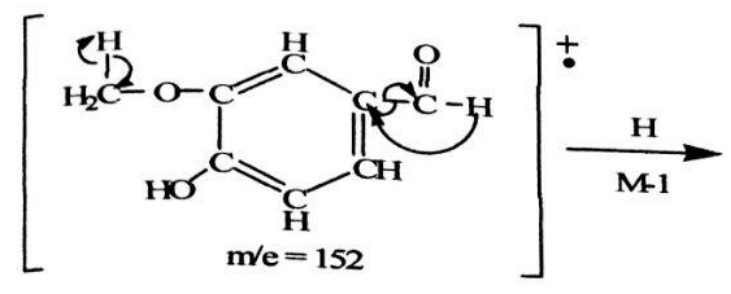<smiles>CCCCCC(=O)c1ccc(O)c(OC)c1</smiles><smiles>C=C</smiles><smiles>OCCOc1ccccc1O</smiles><smiles>CCCCCCCCCCC</smiles><smiles>CCCCCCCCCCCC</smiles><smiles>C=CC1(C)CCCCC1</smiles>
$\mathrm{m} / \mathrm{e}=53$<smiles>O=C(O)Cc1ccccc1O</smiles><smiles>CC(C)C1CC1</smiles>

$\mathrm{m} / \mathrm{e}=109$

O $\$-16<smiles>C/C=C\C(=O)C1CCCC1</smiles>

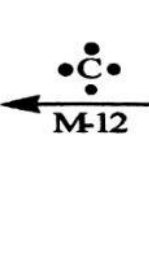<smiles>Oc1ccccc1O</smiles>

Gambar 4. Pola fragmentasi dari senyawa 4-hidroksi-3-metoksi benzaldehida (vanillin)

b. Identifikasi Senyawa pada puncak $4 T_{R} 15,258$ dan $\%$ area 9,46 Spektra massa senyawa ditunjukkan pada Gambar 5. 


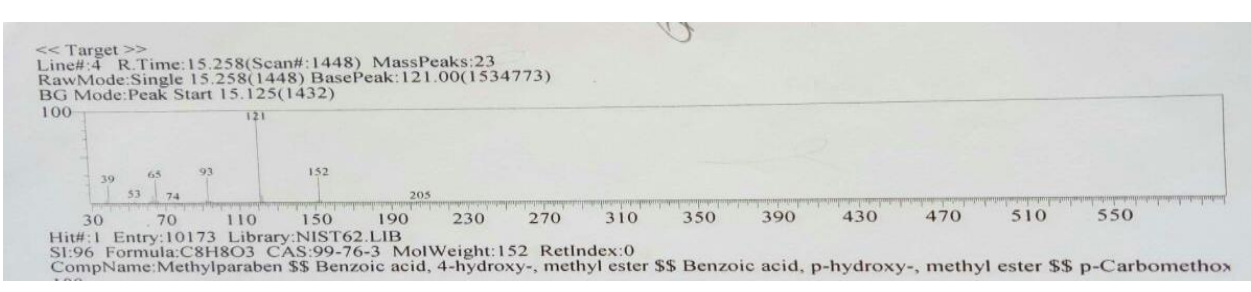

Gambar 5. Spektra massa senyawa puncak 4 fraksi eter pada $T_{R} 15,258$ dan $\%$ area 9,46

Pada spektra massa yang ditunjukkan pada gambar, tampak puncak ion molekul ion $\mathrm{M}^{+} \mathrm{m} / \mathrm{e}=152$. Berdasarkan data base KG-SM ditampilkan senyawa yang memiliki kemiripan 96\% dengan senyawa pada puncak 4 . Senyawa tersebut adalah 4-hidroksil metil ester benzoat (metil paraben) dengan rumus molekul $\mathrm{C}_{8} \mathrm{H}_{8} \mathrm{O}_{3}$ dan harga $\mathrm{DBE}=5$. Puncak-puncak lainnya muncul pada m/e 121, 93, 65, 53, dan 39. Pada m/e 121 merupakan puncak dasar. Senyawa pada $\mathrm{M}^{+} \mathrm{m} / \mathrm{e} 152$ melepaskan molekul $\mathrm{OCH}_{3}$ menghasilkan fragmen m/e 121. Fragmen m/e 121 melepaskan molekul CO menghasilkan fragmen m/e 93. Fragmen m/e 93 melepaskan molekul CO menghasilkan fragmen $\mathrm{m} / \mathrm{e}$ 65. Fragmen $\mathrm{m} / \mathrm{e} 65$ melepaskan atom $\mathrm{C}$ menghasilkan fragmen $\mathrm{m} / \mathrm{e} 53$. Fragmen $\mathrm{m} / \mathrm{e} 53$ melepaskan molekul $\mathrm{CH}_{2}$ menghasilkan fragmen $\mathrm{m} / \mathrm{e}$ 39.

Pola fragmentasi dari senyawa 4-hidroksi-metil benzoat (metil paraben) dijelaskan pada Gambar 6. 

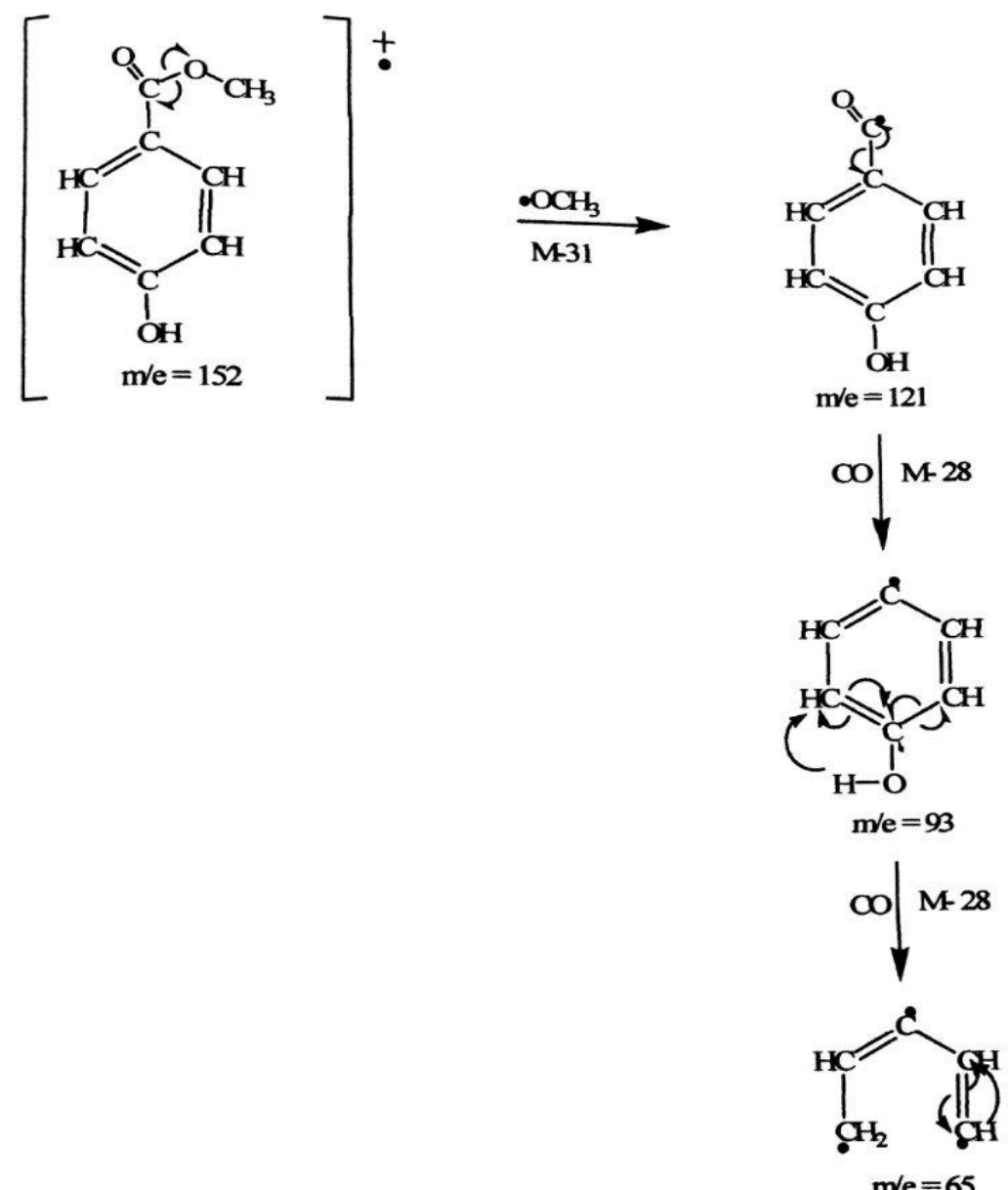

$\mathrm{m} / \mathrm{e}=65$

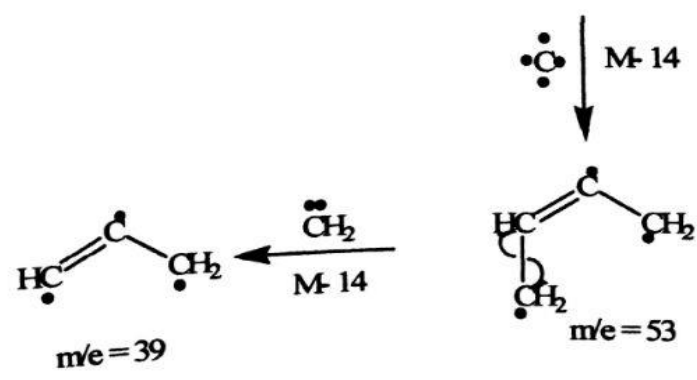

Gambar 6. Pola fregmentasi senyawa 4-hidroksi-metil benzoat (metil paraben) 


\section{c. Identifikasi Senyawa pada puncak $6 T_{R} 17,117$ dan $\%$ area 11,56}

Spektra massa senyawa ditunjukkan pada Gambar 7.

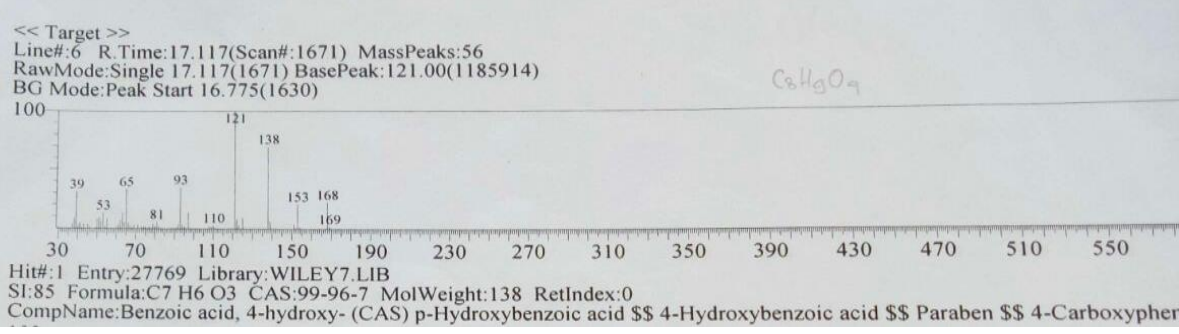

Gambar 7. Spektra massa senyawa puncak 6 fraksi eter pada $T_{R} 17,117$ dan $\%$ area 11,56

Pada spektra massa yang ditunjukkan pada gambar, tampak puncak ion molekul ion $\mathrm{M}^{+} \mathrm{m} / \mathrm{e}=168$ dan rumus molekul $\mathrm{C}_{8} \mathrm{H}_{8} \mathrm{O}_{3}$ dan harga $\mathrm{DBE}=5$. Puncak-puncak lainnya muncul pada m/e 138, 121, 93, 81, 65, 53, dan 39. Pada m/e 121 merupakan puncak dasar. Senyawa pada $\mathrm{M}^{+} \mathrm{m} / \mathrm{e} 168$ melepaskan molekul $\mathrm{CH}_{2} \mathrm{O}$ menghasilkan fragmen m/e 138. Fragmen m/e 121 melepaskan molekul CO menghasilkan fragmen m/e 93. Fragmen m/e 93 melepaskan atom $\mathrm{C}$ menghasilkan fragmen m/e 81. Fragmen 81 melepaskan atom $\mathrm{O}$ menghasilkan menghasilkan fragmen m/e 65. Fragmen m/e 65 melepaskan atom $\mathrm{C}$ menghasilkan fragmen $\mathrm{m} / \mathrm{e} 53$. Fragmen $\mathrm{m} / \mathrm{e} 53$ melepaskan molekul $\mathrm{CH}_{2}$ menghasilkan fragmen m/e 39 .

Pola fragmentasi dari senyawa 4-hidroksi-3-metoksi benzoat (asam vanilat) dijelaskan pada Gambar 8. 


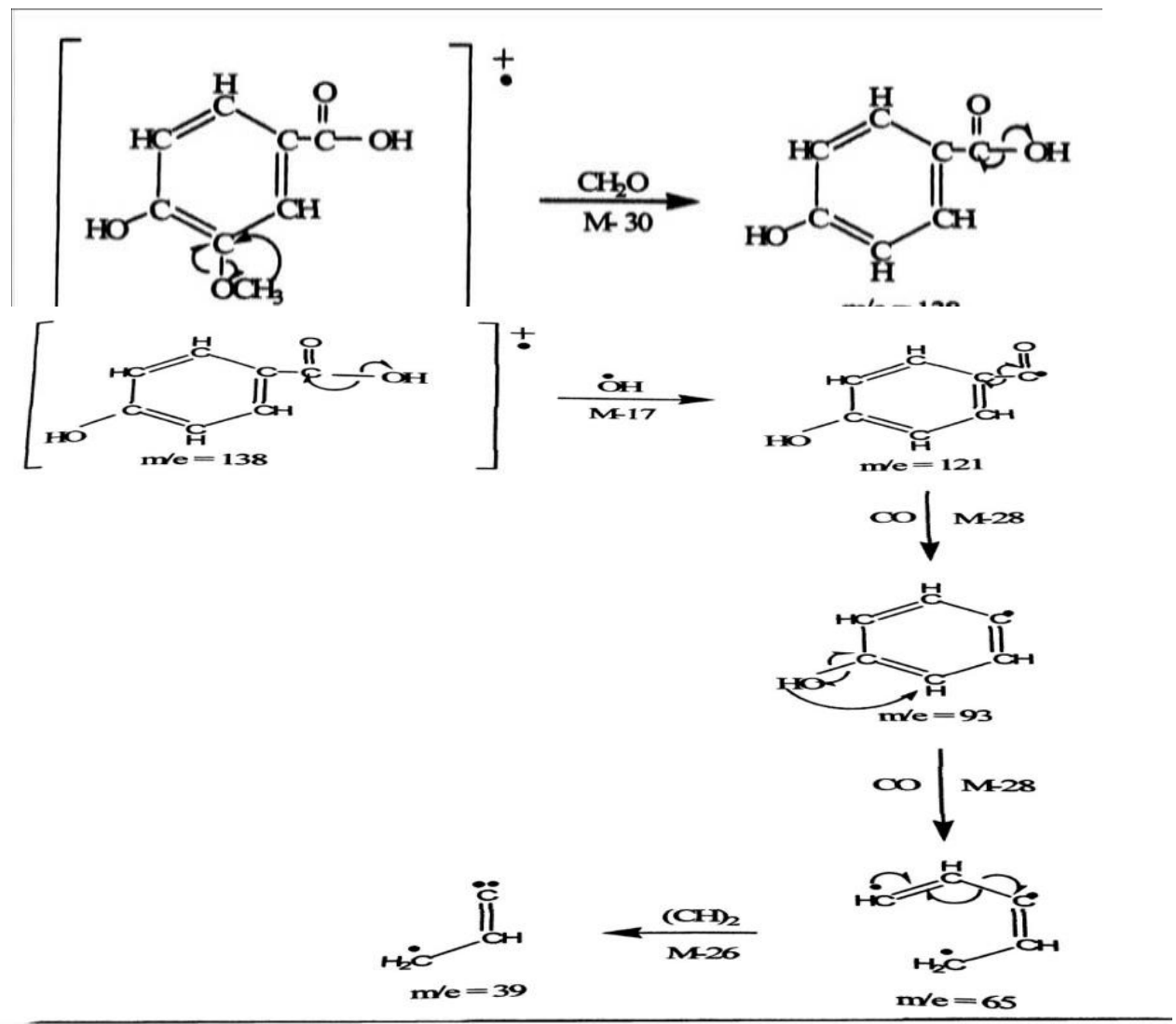

Gambar 8. Pola fragmentasi senyawa 4-hidroksi-metoksi benzoat (asam vanilat)

\section{d. Identifikasi senyawa pada puncak $7 T_{R} 17,950$ dan $\%$ area 72,70}

Spektra massa senyawa ditunjukkan pada Gambar 9

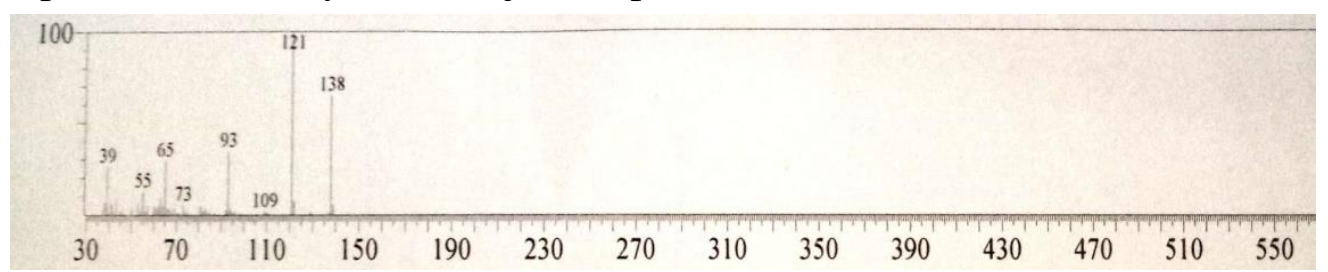

Gambar 9. Spektra massa senyawa puncak 7 fraksi eter pada $T_{R} 17,950$ dan $\%$ area 72,70

Pada spektra massa yang ditunjukkan pada gambar, tampak puncak ion molekul ion $\mathrm{M}^{+}, \mathrm{m} / \mathrm{e}=138$. Berdasaekan data base $\mathrm{KG}-\mathrm{SM}$ ditampilkan senyawa yang memiliki kemiripan 90\% dengan senyawa pada puncak 7 . Senyawa tersebut adalah 4-hidroksi benzoat (paraben) dengan rumus molekul $\mathrm{C}_{7} \mathrm{H}_{6} \mathrm{O}_{3}$ dan harga $\mathrm{DBE}=5$. Puncak-puncak lainnya muncul pada $\mathrm{m} / \mathrm{e} 121$, 109, 93, 65, dan 39. Pada m/e 121 merupakan puncak dasar. Senyawa pada 
$\mathrm{M}^{+}$m/e 138 melepaskan molekul $\mathrm{OH}$ menghasilkan fragmen m/e 121. Fragmen m/e 121 melepaskan molekul CO menghasilkan fragmen m/e 93. Fragmen m/e 93 melepaskan atom CO menghasilkan fragmen m/e 65 .

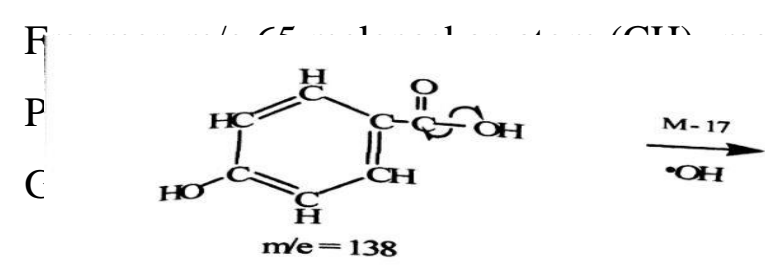<smiles>C=C(C)CCCCC</smiles><smiles></smiles>

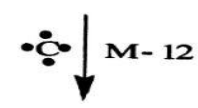<smiles>[Zn]=C/C=C\[Ga]</smiles>

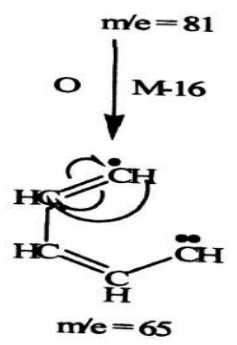

Gambar 13. Pola fragmen senyawa 3-hidroksi benzoat (paraben)

5. Analisis Kromatografi gas-spektroskopi massa (KG-SM) pada fraksi kloroform ekstrak buah laban

a. Identifikasi senyawa pada puncak $2 T_{R} \quad 13,433$ dengan persen area 1,85

Spektra massa senyawa ditunjukkan pada Gambar 10. 


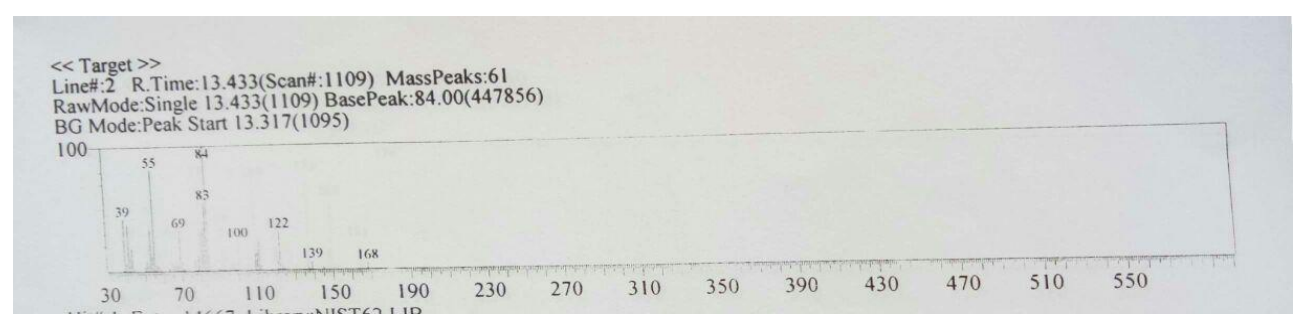

Gambar 10. Spektra massa senyawa puncak 2 fraksi kloroform pada $T_{R}$ 13,433 dengan $\%$ area 1,85

Pada spektra massa yang ditunjukkan pada gambar, tampak puncak ion molekul $\mathrm{M}^{+}, \mathrm{m} / \mathrm{e}=168$ dan rumus molekul $\mathrm{C}_{9} \mathrm{H}_{12} \mathrm{O}_{3}$ dengan harga $\mathrm{DBE}=4$. Puncak-puncak lainnya muncul pada m/e 139, 122, 84, 55, dan 39. Pada m/e 84 merupakan puncak dasar. Senyawa pada $\mathrm{M}^{+}$, m/e 168 melepaskan molekul $\mathrm{CH}_{2} \mathrm{CH}_{3}$ menghasilkan fragmen m/e 139. Fragmen m/e 139 melepaskan molekul $\mathrm{OH}$ menghasilkan fragmen m/e 122. Fragmen m/e 122 melepaskan molekul $\mathrm{C}_{3} \mathrm{H}_{8}$ menghasilkan m/e 84. Fragmen m/e 84 melepaskan molekul CHO menghasilkan fragmen m/e 55. Fragmen m/e 55 melepaskan atom O menghasilkan fragmen m/e 39.

Pola fragmentasi senyawa $\alpha$-butil ester furoat dijelaskan pada Gambar 15.

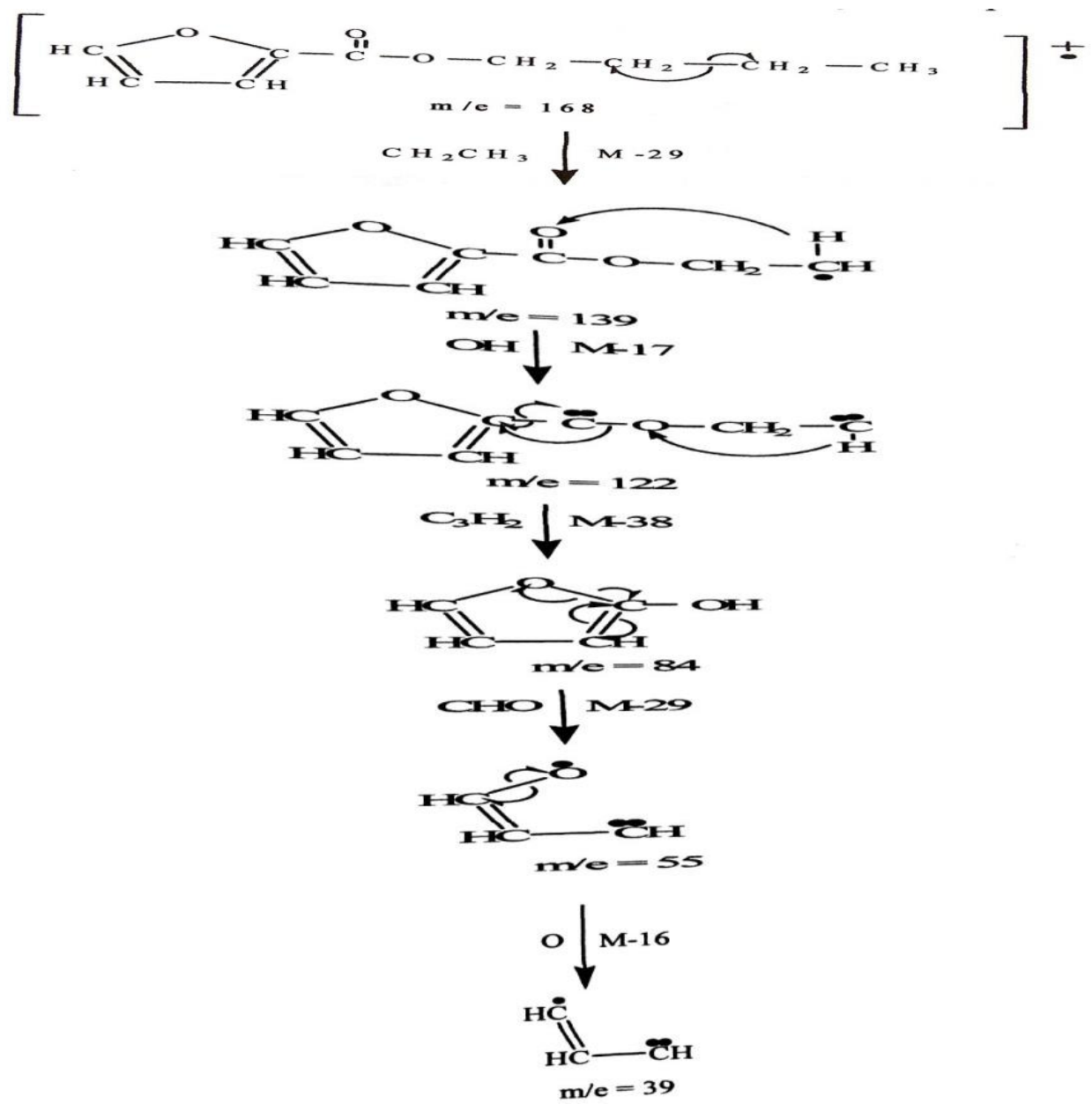


Gambar 15. Pola fragmentasi senyawa $\alpha$-butil ester furoat

\section{b. Identifikasi senyawa pada puncak $15 \mathrm{~T}_{\mathrm{R}} \mathbf{1 8 , 6 3 3}$ dan $\%$ area 2,89} Spektra massa senyawa ditunjukkan pada Gambar 11.

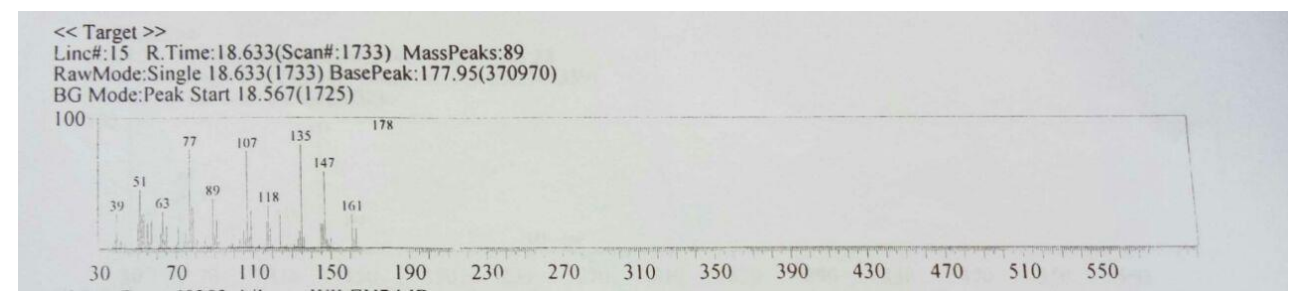

Gambar 16. Spektra massa senyawa puncak 15 fraksi kloroform pada $T_{R}$ 18,633 dan $\%$ area 2,89

Pada spektra massa yang ditunjukkan pada gambar, tampak puncak ion molekul $\mathrm{M}^{+}, \mathrm{m} / \mathrm{e}$ 178. Berdasarkan data base KG-SM ditampilkan senyawa yang memiliki kemiripan $79 \%$ dengan senyawa pada puncak 15 . Senyawa tersebut adalah 4-hidroksi-3-metoksi sinamaldehida (4-hidroksi-3-metoksi phenil-2-propenal) rumus molekul $\mathrm{C}_{10} \mathrm{H}_{10} \mathrm{O}_{3}$ dan harga $\mathrm{DBE}=6$. Puncakpuncak lainnya muncul pada m/e 161, 147, 118, 89, 77, 51, dan 39. Pada m/e 178 merupakan puncak dasar. Senyawa pada $\mathrm{M}^{+}$, m/e 178 melepaskan molekul $\mathrm{OH}$ menghasilkan fragmen 161. Fragmen m/e 161 melepaskan molekul $\mathrm{CH}_{2}$ menghasilkan fragmen m/e 147. Fragmen m/e 147 melepaskan molekul CHO menghasilkan fragmen m/e 188. Fragmen m/e 188 melepaskan molekul CHO menghasilkan fragmen m/e 89. Fragmen m/e 89 melepaskan atom $\mathrm{C}$ menghasilkan fragmen m/e 77. Fragmen m/e 77 melepaskan molekul $(\mathrm{CH})_{2}$ menghasilkan fragmen m/e 51. Fragmen m/e 51 melepaskan atom C menghasilkan fragmen m/e 39 .

Pola fragmentasi senyawa 4-hidroksi-3-metoksi sinamaldehida (4-hidroksi-3metoksi phenil-2-propenal) dijelaskan pada Gambar 11. 


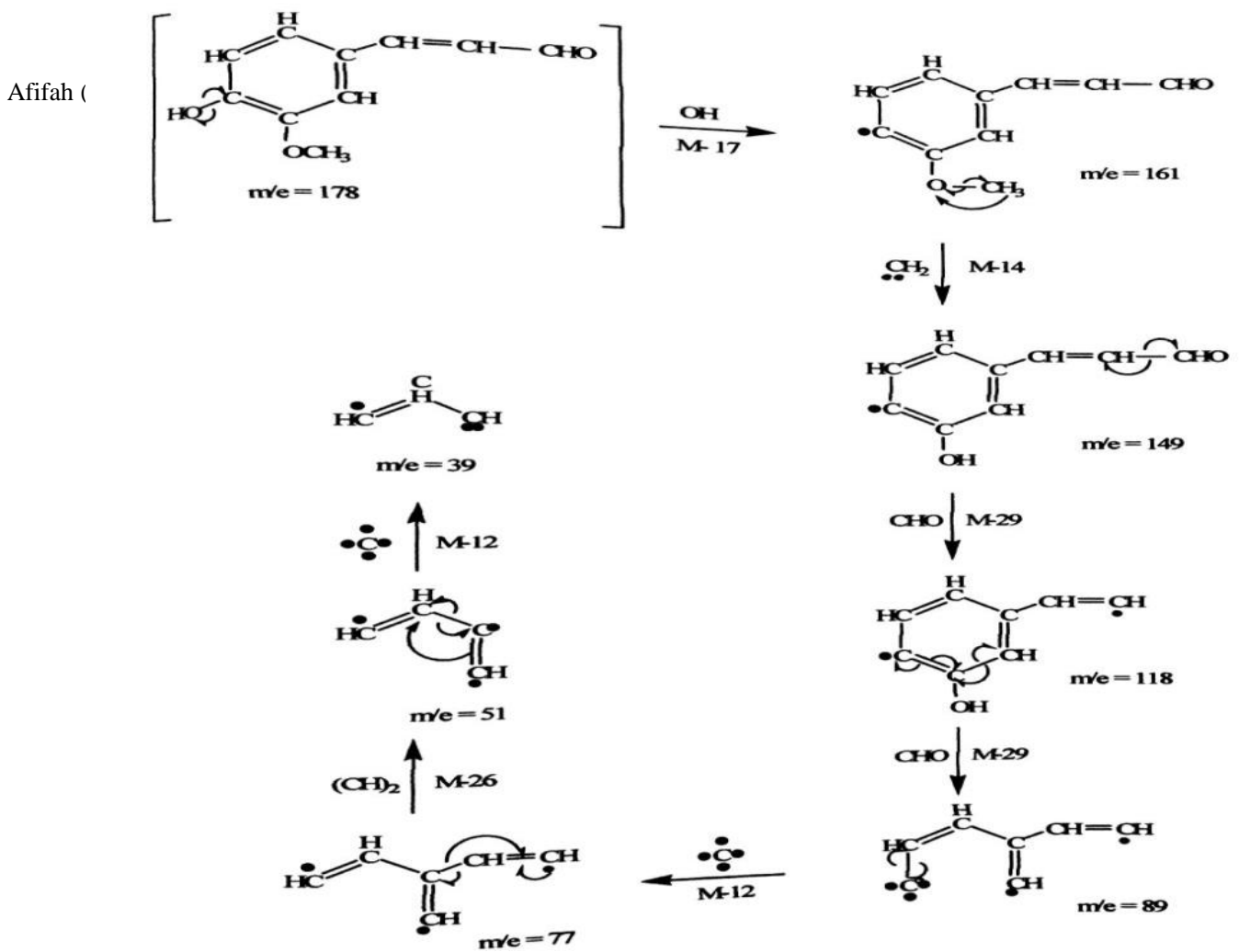

Gambar 17. Pola fragmentasi senyawa 4-hidroksi-3-metoksi sinamaldehida (4-hidroksi-3-metoksi phenil-2-propenal)

c. Identifikasi senyawa pada puncak $33 \mathrm{~T}_{\mathrm{R}} \mathbf{2 4 , 5 2 5}$ dan $\%$ area 4,96 Spektra massa senyawa ditunjukkan pada Gambar 12.

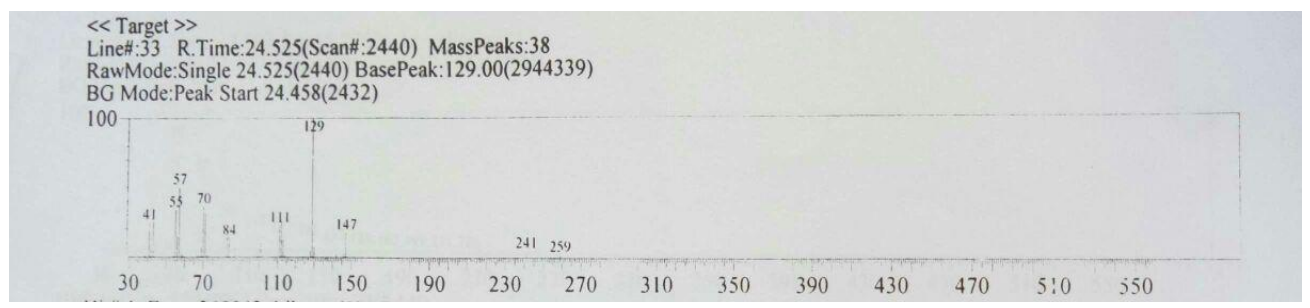

Gambar 12. Spektra senyawa puncak 33 fraksi kloroform pada $T_{R} 24,525$ dan $\%$ area 4,96

Pada spektra massa yang ditunjukkan pada gambar, tampak puncak ion molekul $\mathrm{M}^{+}-111, \mathrm{~m} / \mathrm{e}=259$. Berdasarkan data base KG-SM ditampilakn senyawa yang memiliki kemiripan 97\% dengan senyawa pada puncak 33 . Senyawa tersebut adalah bis 2-etilheksil adipat (sicol) dengan rumus molekul $\mathrm{C}_{22} \mathrm{H}_{42} \mathrm{O}_{4}$ dengan harga $\mathrm{DBE}=2$. Puncak-puncak lainnya muncul pada m/e 241, 147, 129, 111, 84, 70, 57, dan 41. Pada m/e 129 merupakan puncak dasar. Senyawa m/e 370 melepaskan molekul $\mathrm{C}_{8} \mathrm{H}_{15}$ menghasilkan fragmen m/e 259. Fragmen m/e 259 melepaskan molekul $\mathrm{H}_{2} \mathrm{O}$ menghasilkan fragmen m/e 241. Fragmen m/e 241 melepaskan molekul $\mathrm{C}_{6} \mathrm{H}_{8} \mathrm{O}_{2}$ menghasilkan m/e 
129. Fragmen m/e 129 melepaskan molekul $\mathrm{H}_{2} \mathrm{O}$ menghasilkan fragmen m/e 89. Fragemn m/e 89 melepaskan atom C menghasilkan fragmen m/e 77 . Fragmen m/e 77 melepaskan molekul $(\mathrm{CH})_{2}$ menghasilkan fragmen m/e 51 . Fragmen m/e 51 melepaskan atom C menghasilkan fragmen m/e 39.

Pola fragmentasi senyawa bis 2-etilheksil adipat (sicol) dijelaskan pada Gambar 13 .

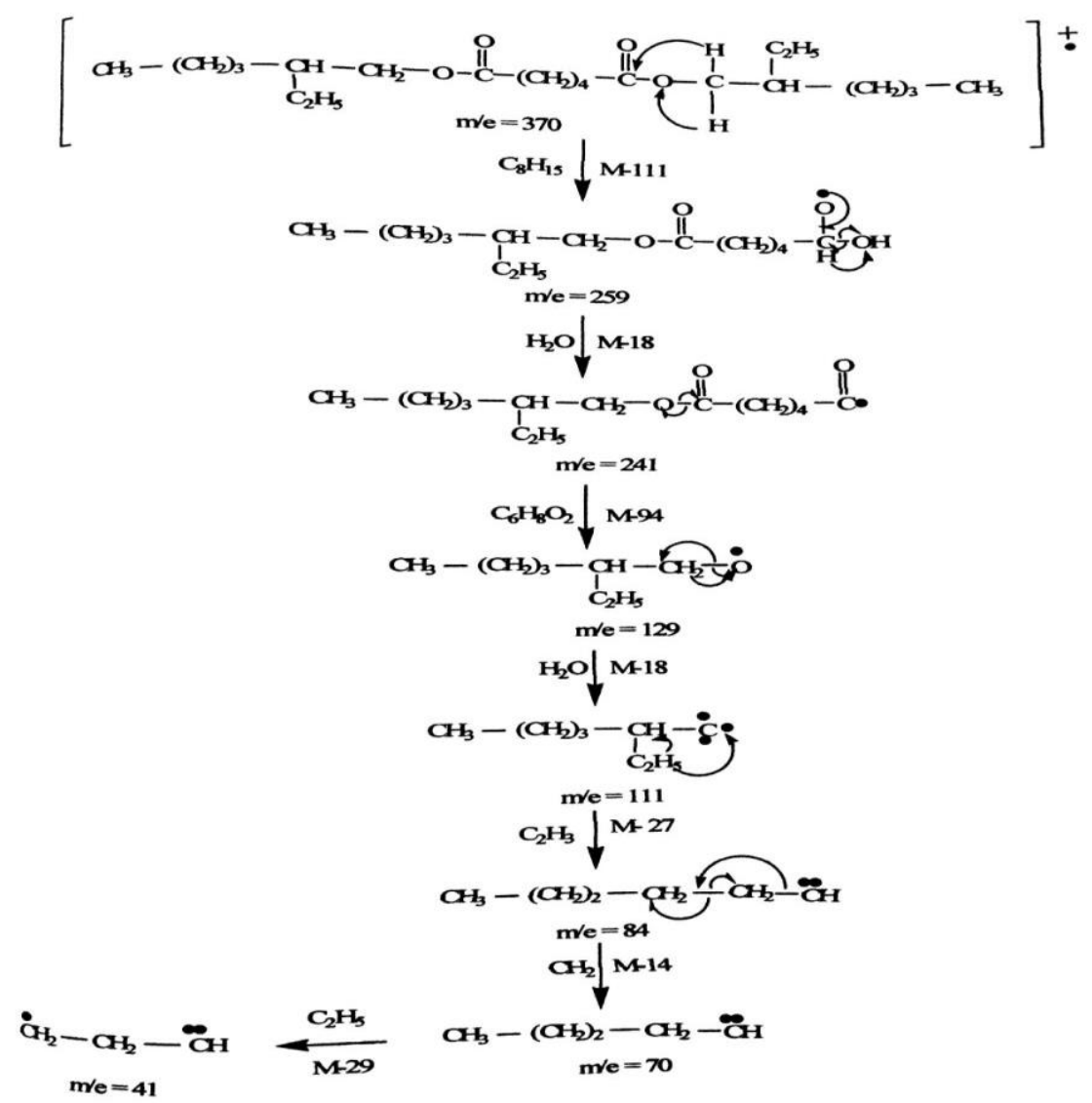

Gambar 13. Pola fragmentasi senyawa bis 2-etilheksil adipat (sicol)

\section{d. Identifikasi senyawa pada puncak $47 \mathrm{~T}_{\mathrm{R}} 27,129$ dan $\%$ area 3,98}

Spektra massa senyawa ditunjukkan pada Gambar 14.

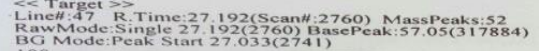

Gambar 14. Spektra massa senyawa puncak $47 \mathrm{~T}_{\mathrm{R}} 27,129$ dan $\%$ area 3,98

Pada Spektra yang ditunjukkan pada gambar, tampak puncak ion molekul $\mathrm{M}^{+}$ $-\mathrm{H}, \mathrm{m} / \mathrm{e}=225$. Senyawa tersebut adalah heksadekana dengan rumus molekul $\mathrm{C}_{16} \mathrm{H}_{34}$ dan harga $\mathrm{DBE}=0$. Puncak-puncak lainnya muncul pada m/e 211, 183, 155, 127, 99, 71, 57, dan 43. Pada m/e 57 merupakan puncak dasar. Senyawa 
pada $\mathrm{M}^{+}-\mathrm{H}, \mathrm{m} / \mathrm{e} 255$ melepaskan molekul $\mathrm{CH}_{2}$ menghasilkan fragmen m/e 211 . Fragmen m/e 211 melepaskan molekul $\left(\mathrm{CH}_{2}\right)_{2}$ menghasilkan m/e 183. Fragmen m/e 183 melepaskan molekul $\left(\mathrm{CH}_{2}\right)_{2}$ menghasilkna m/e 155. Fragmen m/e 155 melepaskan molekul $\left(\mathrm{CH}_{2}\right)_{2}$ menghasilkan fragmen m/e 127. Fragmen m/e 127 melepaskan molekul $\left(\mathrm{CH}_{2}\right)_{2}$ menghasilkan fragmen m/e 99. Fragmen m/e 99 melepaskan molekul $\left(\mathrm{CH}_{2}\right)_{2}$ menghasilkan fragmen m/e 71 . Fragmen m/e 71 melepaskan molekul $\mathrm{CH}_{2}$ menghasilkan fragmen m/e 57. Fragmen m/e 57 melepaskan molekul $\mathrm{CH}_{2}$ menghasilkan fragmen m/e 43 .

Pola fragmentasi senyawa heksadekana dijelaskan pada Gambar 14.

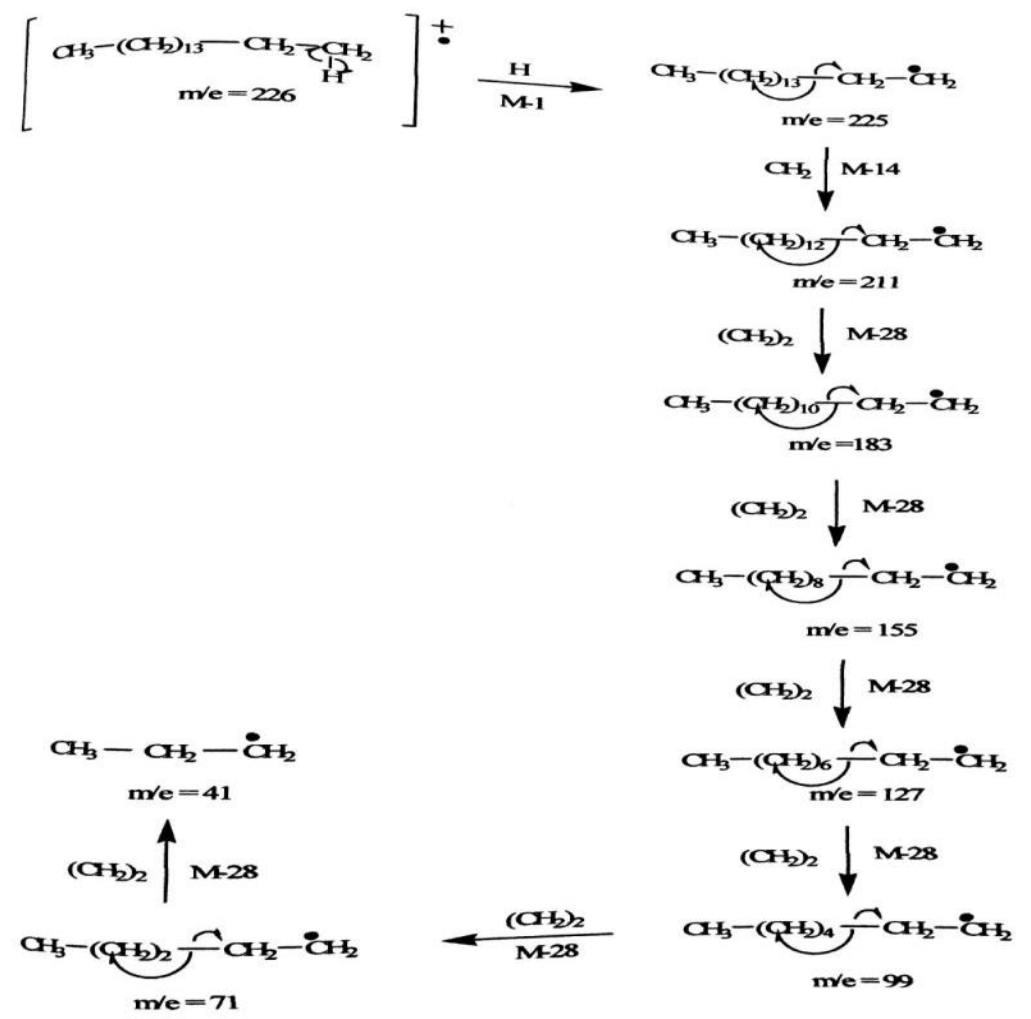

Gambar 21. Pola fragmentasi senyawa heksadekana

e. Identifikasi senyawa pada puncak $50 \mathrm{~T}_{\mathrm{R}} \mathbf{2 7 , 7 7 9}$ dan $\%$ area 4,64 Spektra massa senyawa ditunjukkan pada Gambar 15.

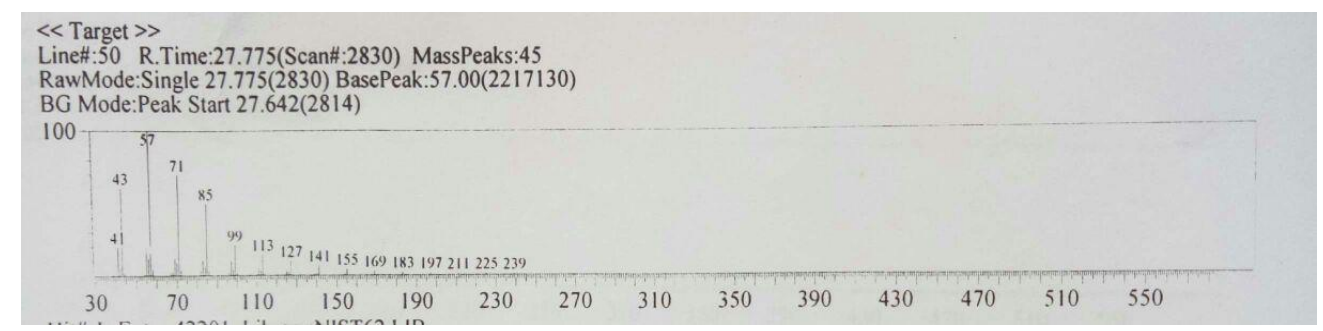


Gambar 15. Spektra massa senyawa puncak 50 fraksi kloroform pada $T_{R}$ 27,779 dan $\%$ area 4,64

Pada spektra massa yang ditunjukkan pada gambar, tampak puncak ion molekul $\mathrm{M}^{+}-\mathrm{H}, \mathrm{m} / \mathrm{e}=239$. Senyawa tersebut adalah heptadekana dengan rumus molekul $\mathrm{C}_{17} \mathrm{H}_{36}$ dan harga $\mathrm{DBE}=0$. Puncak-puncak lainnya muncul pada m/e 211, 183, 155, 127, 99, 71, 57, dan 43. Pada m/e 57 merupakan puncak dasar. Senyawa pada $\mathrm{M}^{+}-\mathrm{H}$ m/e 259 melepaskan molekul $\left(\mathrm{CH}_{2}\right)_{2}$ menghasilkan fragmen m/e 211. Fragmen m/e 211 melepaskan molekul $\left(\mathrm{CH}_{2}\right)_{2}$ menghasilkan fragmen $\mathrm{m} / \mathrm{e} 183$. Fragmen m/e 183 melepaskan molekul $\left(\mathrm{CH}_{2}\right)_{2}$ menghasilkan fragmen $\mathrm{m} / \mathrm{e}$ 155. Fragmen $\mathrm{m} / \mathrm{e} 155$ melepaskan molekul $\left(\mathrm{CH}_{2}\right)_{2}$ menghasilkan fragmen m/e 127. Fragmen m/e 127 melepaskan molekul $\left(\mathrm{CH}_{2}\right)_{2}$ menghasilkan fragmen m/e 99. Fragmen m/e 99 melepaskan molekul $\left(\mathrm{CH}_{2}\right)_{2}$ menghasilkan fragmen m/e 71. Fragmen m/e 71 melepaskan molekul $\mathrm{CH}_{2}$ menghasilkan fragmen m/e 57. Fragmen m/e 57 melepaskan molekul $\mathrm{CH}_{2}$ menghasilkan fragmen m/e 43.

Pola fragmentasi senyawa heptadekana dijelaskan pada Gambar 16.

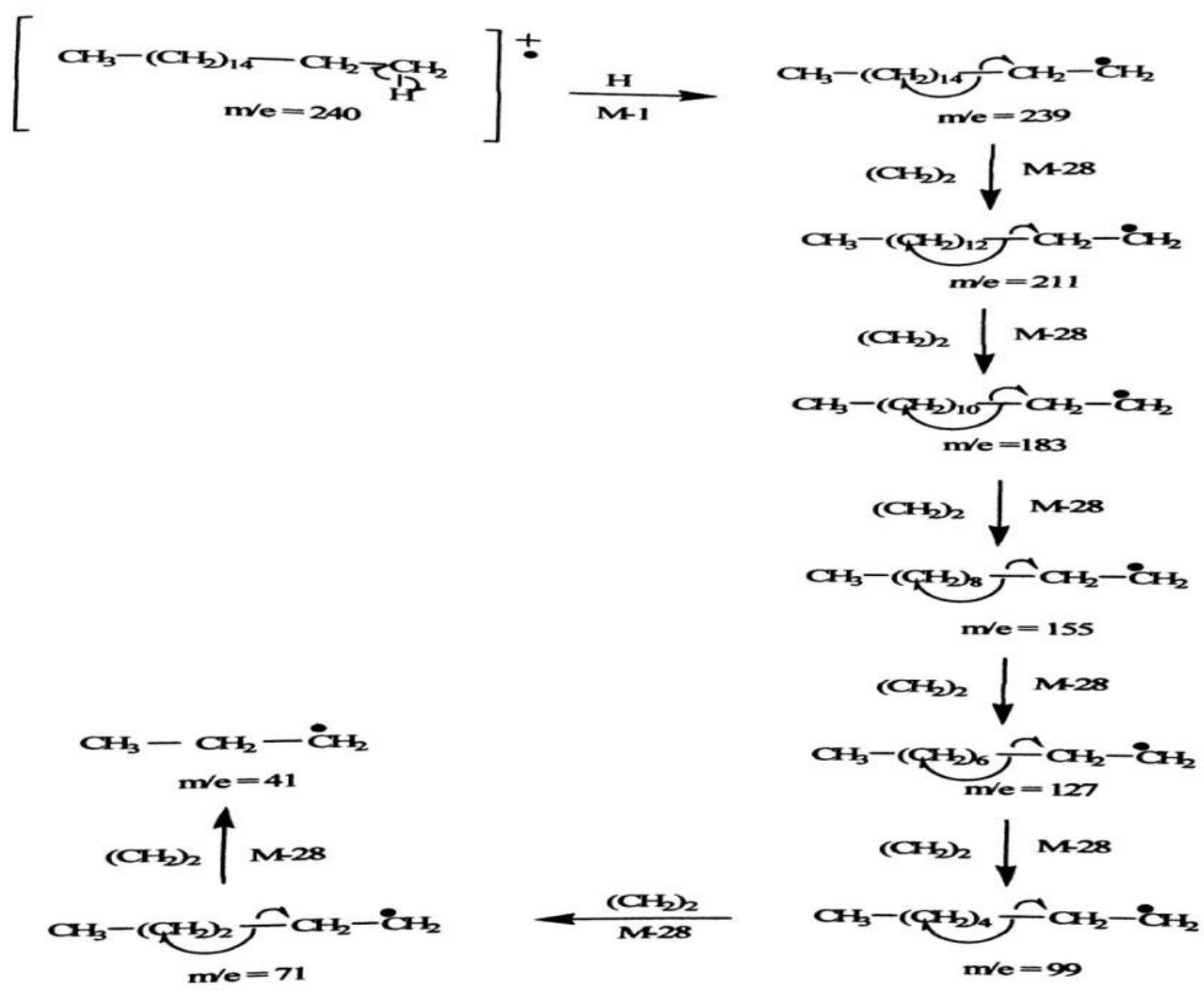


Gambar 16. Pola fragmentasi senyawa heptadekana

Dari hasil analisis spektroskopi massa diperoleh beberapa senyawa penyusun ekstrak buah laban seperti terlihat pada Tabel 8 .

Tabel 8. Puncak-puncak dominan dari kromatogram hasil KG-SM fraksi eter dan fraksi kloroform ekstrak buah laban

\begin{tabular}{|l|c|c|l|c|}
\hline \multicolumn{1}{|c|}{ Fraksi } & $\begin{array}{c}\text { No. } \\
\text { Puncak }\end{array}$ & $\mathbf{T}_{\mathbf{R}}$ & \multicolumn{1}{|c|}{ Nama Senyawa } & \% area \\
\hline Eter & 3 & 14,234 & 4-hidroksi-3-metoksi & $2,97 \%$ \\
& 4 & 15,258 & benzaldehida (vanillin) & $9,46 \%$ \\
& 6 & 17,117 & 4-hidroksi-3-metil ester benzoat & $11,56 \%$ \\
& 7 & 17,950 & (metil paraben) & $72,70 \%$ \\
& & & 4-hidroksi-3-metoksi benzoat & \\
& & & (asam vanilat) & \\
\hline Kloroform & 2 & 13,433 & a-hidroksi benzoat (paraben) & $1,85 \%$ \\
& 15 & 18,633 & 4-hidroksi-3-metoksi & $2,89 \%$ \\
& 33 & 24,525 & sinamaldehida & $4,96 \%$ \\
& 47 & 27,192 & Bis-2-etilheksil adipate (sicol) & $3,98 \%$ \\
& 50 & 27,779 & Heksadekana & $4,64 \%$ \\
& & & Heptadekana & \\
\hline
\end{tabular}

Pada Tabel 10, terdapat 4 puncak dominan pada fraksi eter dan 5 puncak dominan pada fraksi kloroform yang dilihat berdasarkan besarnya persen area. Pada fraksi eter komponen senyawa yang teridentifikasi semuanya merupakan senyawa asam fenolat, dimana asam fenolat yang larut dalam eter akan terbebaskan dari hidrolisis jaringan tumbuhan dalam suasana asam (Harbone, 1996).

Sedangkan pada fraksi kloroform senyawa yang teridentifikasi, yaitu; (1) $\alpha$ butil ester furoat merupakan senyawa dengan cincin furan dan mempunyai gugus karboksilat. Fura bersifat aromatik karena satu pasangan menyendiri elektron pada atom oksigen terdelokalisasi ke dalam cincin, menghasilkan sistem aromatik 4n+2 yang sama dengan benzena (wikipedia, 2009), (2) 4hidroksi-3-metoksi sinamaldehida merupakan senyawa fenolik dengan gugus aldehida. Sinamaldehida merupakan turunan dari senyawa fenol (Azima, 2008), dan termasuk ke dalam golongan minyak atsiri (Anwar,dkk.1996), (3) bis 2-etilheksil adipat (sicol) merupakan senyawa golongan ester yang merupakan turunan dari asam adipat dan merupakan golongan terpenoid yaitu 
diterpenoid, (4) n-heksadekana dan n-heptadekana merupakan senyawa golongan alkana yang bersifat nonpolar.

\section{Pemanfaatan Senyawa Hasil Identifikasi}

Berdasarkan hasil identifikasi yang diperoleh dari fraksi eter ekstrak buah laban senyawa-senyawa yang teridentifikasi adalah senyawa-senyawa asam fenolat yang dapat dimanfaatkan antara lain :

1. 4-hidroksi-metil ester benzoat (metil paraben) dan 4-hidroksi benzoat (paraben) merupakan senyawa fenolik yang mempunyai gugus karboksilat, kedua senyawa ini banyak digunakan sebagai zat pengawet dalam industri kosmetik. Selain itu juga merupakan senyawa yang bersifat antioksidan (Muhaimin,2008). Antioksidan adalah senyawa yang mampu menghambat proses autooksidasi pada semua bahan yang mengandung lipid. Antioksidan merupakan sebutan untuk zat yang berfunsi melindungi tubuh dari serangan radikal bebas. Antioksidan membantu menghentikan proses perusakan sel dengan cara memberikan elektron kepada radikal bebas. Antioksidan akan menetralisir radikal bebas sehingga tidak mempunyai kemampuan lagi mencuri elektron dari sel atau DNA. Antioksidan alami kebanyakan dalam bentuk senyawa fenolik. Gugus fenol pada antioksidan inilah yang mampu menangkap radikal bebas dari rantai peroksida (ROO).

2. 4-hidroksi-3-metoksi benzaldehida (vanilin) juga menunjukkan aktivitas sebagai antioksidan (Aini, dkk, 2006). Literatur media kuno menyebutkan manfaat vanilin sebagai afrodisiak (peningkat nafsu seksual) dan pengobat demam. Manfaat vanilin tersebut belum diujikan secara ilmiah, namun telah dibuktikan bahwa vanilin mampu meningkatkan kadar katekolamin (termasuk epinefrin, yang lebih dikenal sebagai adrenalin), sehingga vanilin dapat menimbulkan efek ketagihan (Apoteker.info).

3. 4-hodroksi-3-metoksi benzoat (asam vanilat) juga merupakan suatu senyawa fenolik yang juga sering digunakan dalam dunia kedokteran sebagai kandungan obat anti peradangan. 
Sedangkan berdasarkan hasil identifikasi yang diperoleh dari fraksi kloroform ekstrak buah laban terdapat beberapa senyawa dominan yang dapat dimanfaatkan antara lain:

1. 4-hidroksi-3-metoksi sinamaldehida merupakan senyawa fenolik dengan gugus aldehida. Di dunia kedokteran, senyawa sinamaldehida diketahui memiliki sifat anti-agregasi platelet dan sebagai vasodilator secara in-vitro. Platelet adalah kolesterol yang menempel pada pembuluh darah. Agregasi (pengumpulan) platelet menyebabkan terjadinya asterosklerosis atau lemak mengeras di pembuluh arteri pada makhluk hidup (Azima, 2008). Sedangkan menurut Tohawa dan Indriati (2008) sinamaldehida juga bersifat fungisida.

2. Bis 2-etilheksil adipat (sicol) atau yang dalam nama dagangnya lebih dikenal dengan DEHA merupakan senyawa golongan ester yang merupakan turunan dari asam adipat. Asam adipat (tatanama IUPAC: asam heksanadioat) adalah sejenis asam dikarboksilat. Asam adipat berupa bubuk kristal putih. Oleh karena rantai alifatik yang panjang, ia tidaklah sangat larut dalam air. Kegunaan utama asam adipat adalah sebagai monomer untuk produksi nilon melalui reaksi polikondensasi denagn heksametilena diamina, membentuk 6,6nilon. Kegunaan lainnya meliputi: monomer untuk produksi poliuretana, rekstan untuk membentuk komponen pemlastis dan pelumas, bumbu masakan sebagai penyedap rasa (wikipedia, 2009).

3. n-heksadekana merupakan senyawa golongan alkana yang mempunyai aktivitas sebagai penunjang pembentukan biosurfaktan (Nugroho, 2006) dan juga dimanfaatkan sebagai minyak pelumas (Yoad, 2007).

\section{SIMPULAN}

1. Berdasarkan hasil KG-SM pada fraksi eter ekstrak buah laban diperoleh 4 senyawa yang dominan yaitu; (1) 4-hidroksi-3-metoksi benzaldehida atau vanilin $(2,97 \%),(2)$ 4-hidroksi-metil ester benzoat atau metil paraben $(9,46 \%)$, (3) 4-hidroksi-3-metoksi benzoat atau asam vanilin (11,56\%), dan (4) 4hidroksi benzoat atau paraben $(72,70 \%)$ 
2. Berdasarkan hasil KG-SM pada fraksi kloroform ekstrak buah laban diperoleh 5 senyawa yang dominan yaitu; (1) $\alpha$-butil ester furoat $(1,85 \%),(2) 4$-hidroksi3-metoksi sinamaldehida (2,89\%), (3) bis-2-etilheksil adipat atau sicol (4,96\%), (4) n-heksadekana (3,98\%), dan (5) n-heptadekana (4,64\%).

\section{DAFTAR PUSTAKA}

Abidin. (1990). STudi Tentang Kadar Air Beberapa Jenis Kayu dari Hutan Alaban (Vitex pubescens Vahl). Banjarmasin: Tidak dipublikasikan.

Heyne, K. (1987). Tumbuhan Berguna Indonesia Jilid III. Jakarta: Yayasan Sarana Wana Jaya.

News, A. (2009). Satu Hektar Hutan Kalimantan Ditumbuhi 200 Jenis Kayu. 